\title{
Effective Surface Charge Density Determines the Electrostatic Attraction between Nanoparticles and Cells
}

\author{
Gaoxing Su, ${ }^{\dagger, \ddagger}$ Hongyu Zhou, ${ }^{\ddagger}$ Qingxin $\mathrm{Mu}^{\ddagger}{ }^{\ddagger}$ Yi Zhang, ${ }^{\dagger,}$ Liwen Li, ${ }^{\dagger,}$ Peifu Jiao, ${ }^{\dagger, \ddagger}$ Guibin Jiang, ${ }^{\S}$ \\ and Bing Yan $*,+,+$ \\ ${ }^{\dagger}$ School of Chemistry and Chemical Engineering, Shandong University, Jinan 250100, China \\ ${ }^{\ddagger}$ Department of Chemical Biology and Therapeutics, St. Jude Children’s Research Hospital, Memphis, Tennessee 38105, United \\ States \\ ${ }^{\S}$ Research Center for Eco-environmental Sciences, Chinese Academy of Sciences, Beijing 100085, China
}

\section{Supporting Information}

ABSTRACT: We examine the origin of the electrostatic attraction between nanoparticle (NP) and cells by synthesizing a NP array with a continuous change in surface charge density (SCD). This attraction does not show a linear and continuous change, but a sharp increase as the positive SCD increases. The results of zeta potential measurements of the naked and protein bound NPs reveal that excessive charges on surface ligands are partially shielded, and the noncovalent protein bindings do not influence NP-cell electrostatic interactions. The effective SCD on the outmost layer of NPs determined the electrostatic attraction between NPs and cells

\section{INTRODUCTION}

The ability of nanoparticles (NPs) to cross cell membranes and other biological barriers presents enormous opportunities for drug and gene delivery and other medicinal applications. ${ }^{1-3}$ However, it also raises societal concerns on the potential toxicity of nanomaterials. ${ }^{4-6}$ Therefore, there is a pressing need to gain a thorough understanding of the fundamental interactions between NPs and cells, which can include electrostatic, hydrophobic, and hydrogen-bonding interactions. $^{7,8}$ Surface charge is related to biological behaviors of NPs, such as tissue diffusing, ${ }^{9}$ biodistribution, ${ }^{10-13}$ cell uptake, ${ }^{11,14-25}$ cytotoxicity, ${ }^{14,22,23,25-29}$ and protein binding. ${ }^{16,30-33}$ Electrostatic interaction between NPs and cells is very important in applications such as gene delivery, ${ }^{34-36}$ cell uptake enhancing, ${ }^{18}$ and endosome escaping. ${ }^{37-39}$ To study electrostatic NP-cell interactions, NPs are normally modified with surface ligand molecules that carry charged functional groups. However, the charged groups often provided the mixed effects of electrostatic and other molecular interactions, which complicate the understanding of basic NP-cell interactions. For example, it is generally assumed that negatively charged NPs should not be taken up by cells because of the repellent interactions with negatively charged lipids on cell membranes. ${ }^{40}$ However, some negatively charged NPs, such as carbon nanotubes $^{20}$ or polystyrene, ${ }^{17}$ can still be taken up by cells via possible involvements of hydrophobic interactions with cell membranes. Studies focusing on understanding the role of isolated electrostatic $\mathrm{NP}-$ cell interactions with minimal or no secondary interactions are still lacking.

In this study, we reveal the electrostatic origin of the NP-cell attraction by separating electrostatic interactions from most other complicated interactions. This was achieved by synthesizing a gold nanoparticle (GNP) array with a continuous change in surface charge density (SCD) with minimal or identical secondary interactions (Figure 1).

\section{EXPERIMENTAL SECTION}

Chemicals were purchased from Acros Organics (Geel, Belgium) and Sigma-Aldrich (St. Louis, MO) and were used without further purification. Peptides (CALRRRRR- $\mathrm{NH}_{2}$ (1), CALRRR-NH $\mathrm{N}_{2}$ (2), CALR-NH $\mathrm{N}_{2}$ (4), CALE-NH $\mathrm{N}_{2}$ (9), CALEE (7), CALEEEE (6)) were synthesized and purified by preparative HPLC in Hartwell Center at St. Jude Children's Research Hospital.

Synthesis of the NP Array. Hydrogen tetrachloroaurate(III) trihydrate $(25.0 \mathrm{mg}, 0.064 \mathrm{mmol})$ was added to a solution of $0.064 \mathrm{mmol}$ of one ligand or two ligands with different ratio (Table S1) in DMF $(20 \mathrm{~mL}$ ) (peptides were dissolved in 20 $\mathrm{mL}$ of water). After stirring for $30 \mathrm{~min}$ at room temperature, sodium tetrahydroborate $(7.2 \mathrm{mg}, 0.19 \mathrm{mmol})$ in $12.0 \mathrm{~mL}$ of water was added to the mixture dropwise. The solution was stirred for $4 \mathrm{~h}$ at room temperature. Then reaction mixture with the excess sodium tetrahydroborate was neutralized by $1 \mathrm{~N}$ $\mathrm{HCl}$. GNPs were purified by dialysis (Spectra/Por dialysis membrane, MWCO: 3500 ) for 48 h or ultrafiltration (MWCO: 5000) and washed for three times.

Transmission Electron Microscope (TEM) Images of GNPs. TEM images of selected GNPs were taken using a JEOL

Received: November 16, 2011

Revised: January 13, 2012

Published: February 1, 2012 


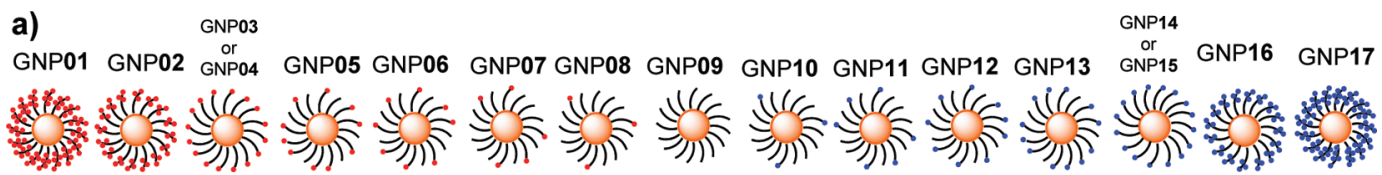

b)

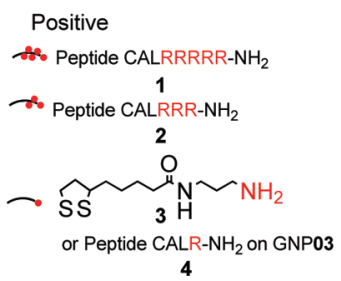

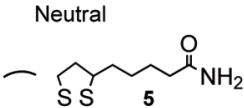

Figure 1. GNP array with a continuous change in surface charge density. (a) 17 members of the GNP array (b) Ligands used to synthesize the GNP array.

1200 EX transmission electron microscope (JEOL, Tokyo, Japan) at $80 \mathrm{kV}$. The images were acquired using an AMT 2k CCD Camera. GNPs were dispersed in water.

Dynamic Light Scattering (DLS) Measurements. Dynamic diameter of GNPs was measured using Dynapro Titan system (Wyatt Technology, Santa Barbara, CA). GNPs were suspended in water or culture medium with $10 \%$ fetal bovine serum (FBS).

Zeta Potential Measurements. Zeta potentials of GNPs were measured in a Malvern Nano Z Zetasizer. Each material was tested three times. Naked GNPs were measured as they prepared. Protein bound GNPs were prepared by dispersing naked GNPs into culture medium with $10 \%$ FBS. After $30 \mathrm{~min}$ incubation, free and loose bound proteins were removed by centrifugation (13000 rpm), and GNPs were washed for three times. The protein bound GNPs were dispersed in water for their zeta potential measurement. To make sure that protein bindings reached equilibrium, zeta potential of selected GNPs, GNP01, -04, -09, -14, and -17, were measured after incubating with proteins for $0.25,0.5,2$, and $6 \mathrm{~h}$. Their zeta potentials were identical (Table S2), suggesting protein bindings reached equilibrium.

Ligand Quantification by the HPLC/MS/CLND Method. GNPs $(2.0 \mathrm{mg})$ were added to a $\mathrm{MeOH}$ solution of $\mathrm{I}_{2}(100$ $\mu \mathrm{L}, 10 \mathrm{mg} / \mathrm{mL}$ ), and the mixture was shaken for $30 \mathrm{~min}$ after a one-minute sonication at room temperature. The complete cleavage of ligands from GNPs has been proved in previous work under these conditions. ${ }^{41}$ The naked GNPs were removed by centrifugation at $13000 \mathrm{rpm}$ for $30 \mathrm{~min}$. $20 \mu \mathrm{L}$ of the supernatant was injected into HPLC/MS/chemiluminescent nitrogen detection (HPLC/MS/CLND) system for analysis. HPLC/MS/CLND was performed on a Waters system equipped with a Waters 2795 separation module, a Micromass ZQ detector, and a Antek 8060-C nitrogen detector. A C18 column $(2.0 \mu \mathrm{m}, 2.0 \times 150 \mathrm{~mm})$ was used for the separation. The mobile phases were methanol and water both containing $0.1 \%$ formic acid. Elution condition: 0 min, $10 \%$ methanol; 4.5 min, 95\% methanol; $5.5 \mathrm{~min}, 95 \%$ methanol; $6.5 \mathrm{~min}, 10 \%$ methanol; $7 \mathrm{~min}, 10 \%$ methanol. Flow rate is $0.7 \mathrm{~mL} / \mathrm{min}$. Mass spectra were recorded in positive ion mode using electrospray ionization. The identity of each ligand was confirmed by the mass spectrometry.

Ligand Quantification by Elemental Analysis. Selected GNPs were dried and sent to Galbraith Laboratories (Knoxville, TN) for elemental analysis. The results of the elemental analysis for $\mathrm{C}, \mathrm{H}$, and $\mathrm{N}$ are all from the coating molecules
(Table S3). The loading of the small molecules on GNPs can be calculated from these values.

Cell Uptake of GNPs. Hela cells were grown in Dulbecco's Modified Eagle Medium (DMEM, Invitrogen, IL). Cell culture medium was supplemented with $10 \% \mathrm{FBS}, 10 \mathrm{U} / \mathrm{mL}$ penicillin, and $10 \mathrm{mg} / \mathrm{mL}$ streptomycin. Cells were seeded in 12-well plates with a density of 200000 cells/well. Cultures were maintained at $37{ }^{\circ} \mathrm{C}$ under a humidified condition with 5\% $\mathrm{CO}_{2}$. After $24 \mathrm{~h}$ of seeding, the cells were washed once with DPBS, and the solutions of GNPs in cell culture medium were added. After incubation in a $5 \% \mathrm{CO}_{2}$, humidified incubator at $37^{\circ} \mathrm{C}$, samples were washed three times with DPBS to remove extra GNPs. The cells were detached by trypsin-EDTA solution ( $0.25 \%$ trypsin, $1 \mathrm{mM}$ EDTA). The detached cells were counted and then prepared for ICP-MS. Each experiment was performed three times.

ICP-MS Measurements. ICP-MS measurements were performed on Varian 820. After detaching and counting of the cells incubated with GNPs, $200 \mu \mathrm{L}$ of resulting cell lysate was digested overnight at $37{ }^{\circ} \mathrm{C}$ by adding $400 \mu \mathrm{L}$ of Aqua Regia. $100 \mu \mathrm{L}$ of the above solution was diluted to $5.0 \mathrm{~mL}$ with a $50 \mathrm{ppb}{ }^{236} \mathrm{Y}$ internal standard solution in $1.0 \% \mathrm{HNO}_{3}$ and used for ICP-MS measurements. A series of gold standard solutions $(1000,500,250,100,50,10,5$, and $1 \mathrm{ppb})$ with 50 $\mathrm{ppb}{ }^{236} \mathrm{Y}$ internal standard were prepared before each measurement. The resulting calibration curve was used to calculate the gold concentration taken up by different cells.

TEM Images of Cells. Cells were treated with GNPs for $2 \mathrm{~h}$ at $50 \mu \mathrm{g} / \mathrm{mL}$ and washed with DPBS for three times. The attached and floating cells were fixed with glutaraldehyde $(2.5 \%$ in $0.1 \mathrm{M}$ of $\mathrm{Na}$-Cacodylate buffer, Tousimis Research Corp.) for $30 \mathrm{~min}$ at room temperature. The samples were washed with DPBS again and sectioned. Ultrathin sections were examined using a JEOL 1200 EX transmission electron microscope (JEOL, Tokyo, Japan). The images were acquired using an AMT 2k CCD Camera.

\section{RESULTS AND DISCUSSION}

Creation a NP Array with Continuous Change in SCD. By varying the ratio of a neutral ligand to a structurally similar ligand with a single negative or positive charge, we synthesized GNP04 to GNP14 (Figure 1). In GNP03-GNP01 and GNP15-GNP17, we fully covered NPs with a single ligand that have 1, 3, or 5 positive or negative charges (Figure 1), making the SCD on NPs even higher. Core diameters of GNPs in this array were $\sim 5 \mathrm{~nm}$, as observed by transmission electron 


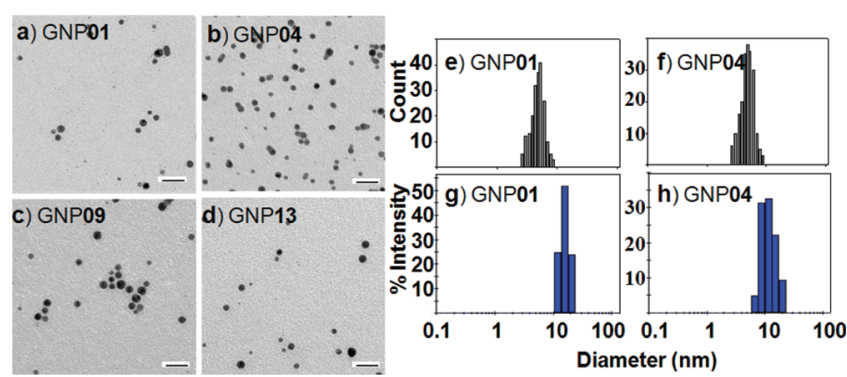

Figure 2. Characterization of GNP's primary size and the aggregation statete. $(\mathrm{a}-\mathrm{d})$ TEM images of GNP01, -04, -09 , and -13 . The scale bar is $20 \mathrm{~nm}$. (e, f) Size distribution of GNP01 and -04 on the basis of TEM images. (g, h) Hydrodynamic diameters of GNP01 and -04 in water measured by DLS.

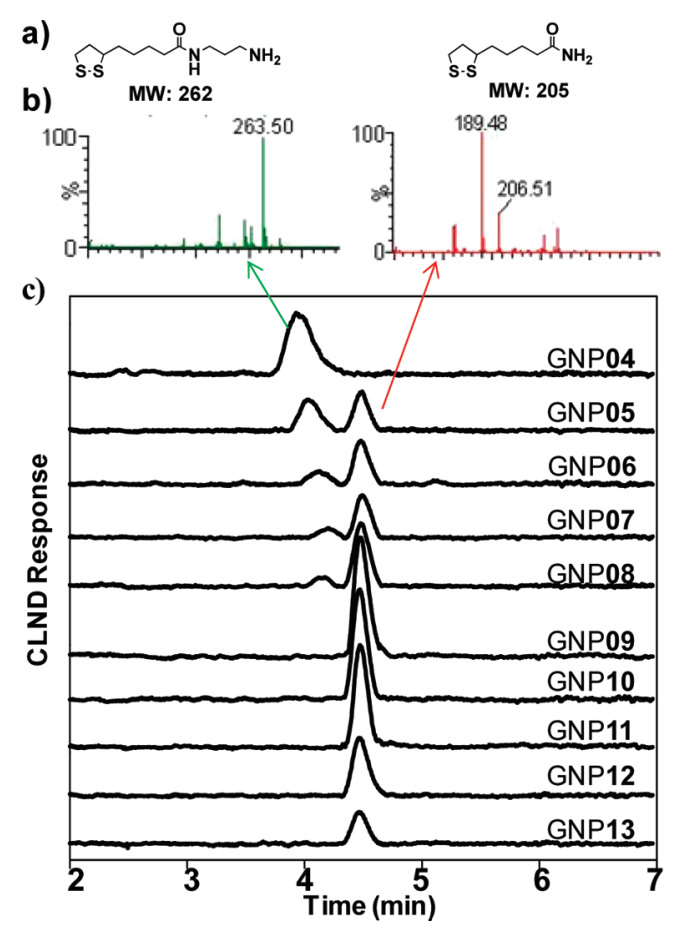

Figure 3. Quantification of GNP-associated ligand molecules by HPLC/MS/CLND. (a) Structures and molecular weights of ligands 3 and 5. (b) Mass spectra of ligands 3 and 5. (c) Quantification of GNP ligands by CLND response of ligands cleaved from GNPs with $\mathrm{I}_{2}$.

microscopy (TEM) (Figure 2a-f). Hydrodynamic diameters of GNPs in water were approximately $10-100 \mathrm{~nm}$ measured by DLS, with highly charged particles showing less aggregation (Figure 2g,h and Figure S1). However, protein-bound GNPs in culture medium had similar hydrodynamic diameters (180 \pm 40 $\mathrm{nm}$; Figure S2).

Characterization of the NP Array's SCD. The authenticity and quantity of ligand (N\%) were measured by elemental analysis for single-ligand modified GNPs and by LC/ $\mathrm{MS} / \mathrm{CLND}^{41}$ for dual-ligand-modified GNPs (Figure 3). SCD for all members incorporation were determined by elemental analysis of nitrogen content of this GNP array were determined experimentally from ligand incorporations after normalization by assuming SCD for GNP03 and GNP04 as +1.0 and GNP14 and GNP15 as -1.0 (Table 1), since these GNPs were $100 \%$ covered by single ligands with a single charge. SCD of the GNP array exhibited a continuous change from +2.87 to -4.18 (Figure $4 \mathrm{a}$ and Table 1). Because SCD of NPs played an
Table 1. Surface Charge Density of the NP Array

$\begin{array}{lllc} & N^{a}(\%) & \text { ligands per NP } & \text { exptl SCD } \\ \text { GNP01 } & 8.17 & 146 & +2.87 \\ \text { GNP02 } & 5.84 & 157 & +1.85 \\ \text { GNP03 } & 4.74 & 254 & +1.0 \\ \text { GNP04 } & 0.67 & 144 & +1.0 \\ \text { GNP05 } & \text { n.a. } & 82(3), 75(5) & +0.52 \\ \text { GNP06 } & \text { n.a. } & 42(3), 102(5) & +0.29 \\ \text { GNP07 } & \text { n.a. } & 31(3), 101(5) & +0.23 \\ \text { GNP08 } & \text { n.a. } & 21(3), 116(5) & +0.15 \\ \text { GNP09 } & 0.54 & 232 & 0 \\ \text { GNP10 } & \text { n.a. } & 201(5), 31(8) & -0.13 \\ \text { GNP11 } & \text { n.a. } & 185(5), 47(8) & -0.20 \\ \text { GNP12 } & \text { n.a. } & 108(5), 124(8) & -0.53 \\ \text { GNP13 } & \text { n.a. } & 62(5), 170(8) & -0.73 \\ \text { GNP14 } & <0.5 & 287 & -1.0 \\ \text { GNP15 } & \text { n.d. } & 299 & -1.0 \\ \text { GNP16 } & 4.21 & 360 & -3.61 \\ \text { GNP17 } & 4.08 & 250 & -4.18\end{array}$

${ }^{a}$ Values from CHN elemental analysis. n.a. = not available; n.d. = not determined. ${ }^{b}$ For GNP01-04, -09, -16, and -17, the number of ligands was calculated according to nitrogen content. For GNP14, the number of ligands was calculated according to carbon content. For GNP05-08 and -10-13, the number of ligands was calculated according to the peak areas of ligand 3 and ligand $\mathbf{5}$ in Figure 3. The matchup of ligand number to peak area was calculated according to number of ligands on GNP04 and GNP09 and their peak area in Figure 3. As ligand 8 had no CLND response, the number of ligand 8 on GNP10-13 was estimate from the difference of an assumed total ligand number (from GNP09) minus the number of ligand 5. The number of ligands for GNP15 was estimated from the average values of the number of ligands on GNP14, 16, and -17. The number in parentheses indicates the ligand identity (ligand numbering) as shown in Figure $1 b .{ }^{c} \mathrm{SCD}$ was determined experimentally based on charged ligands on nanoparticle. SCD values were normalized by assuming SCD of GNP03 and GNP04 were +1.0, and GNP14 and GNP15 were -1.0 . See Supporting Information for details.

important role in gene delivery, ${ }^{34}$ self-assembling protein cages, ${ }^{42}$ protein adsorption, ${ }^{30}$ and immune responses, ${ }^{43}$ this raised the question of whether the electrostatic NP-cell attraction and binding also depend on the continuous electrostatic attraction following this pattern.

Cell Uptake Does Not Parallel Change with SCD of the NP Array. HeLa cells are a widely used cell model because of their close similarities to other human cell lines. The attractions between the GNP array and HeLa cells resulted in cell binding and uptake of GNPs, as quantitatively determined by inductively coupled plasma mass spectrometry (ICP-MS) analysis of gold in cells. In contrast to the linear change of SCD, there was a sharp increase in the cell uptake of the GNP array at GNP05, reaching a level equal to that of the highly positively charged GNP01-GNP04. The uptake was negligible for GNP06-GNP17, the part of the array with less positive, neutral, or negative SCD (Figure $4 \mathrm{~b}$ and Figure S4). From TEM images of cells after incubating with NPs (Figure 5 and Figure S5), we observed large amounts of GNP04, fewer GNP05 and GNP06, and almost no GNP09, GNP12, or GNP14 were bound on the cell surface and taken up by cells. These results were also confirmed by cell images of dark-field microscopy (Figure S6). All GNPs did not show cytotoxicity at $50 \mu \mathrm{g} / \mathrm{mL}$ for $24 \mathrm{~h}$ (Figure S7). These results indicate that cell binding and uptake NPs dispersed in the cell culture medium do not have a linear continuous correlation with the SCD. A 

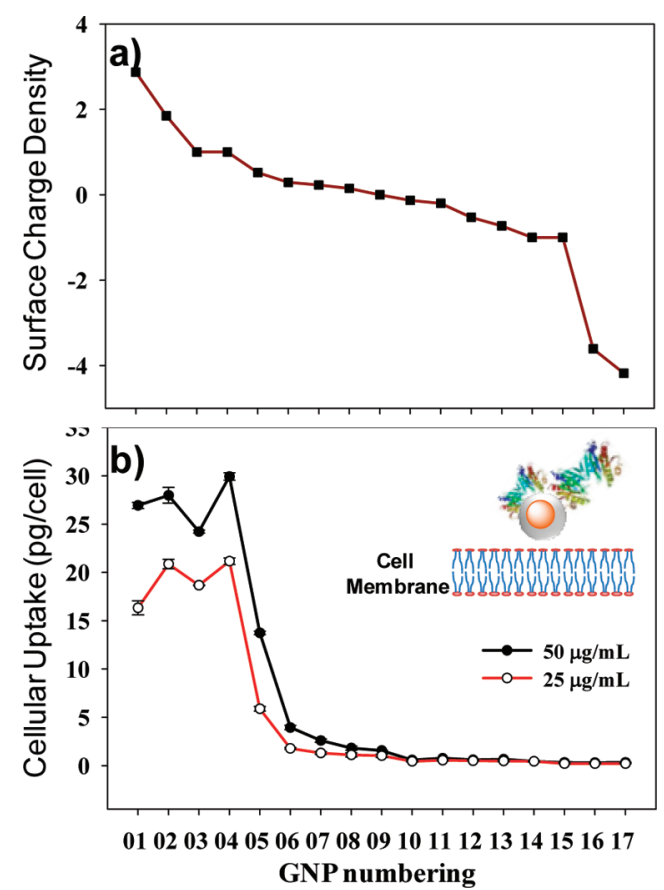

Figure 4. SCD and cell uptake of the GNP array. (a) Surface charge density based on ligand quantification from Table 1. (b) Cellular uptake of the GNP array with a continuous change in SCD in HeLa cells as determined by ICP-MS. Cells were incubated with GNPs for $12 \mathrm{~h}$ at the indicated concentrations. Error bars represent \pm standard deviation.

certain SCD threshold needs to be crossed for the NPs to be taken up by cells. Furthermore, when the positive SCD of NPs is higher than 1.0, the cell attraction and cell uptake effects level off. To determine the causes for the noncontinuity and leveling, we investigated the electrostatic behaviors of the GNP array in solution.

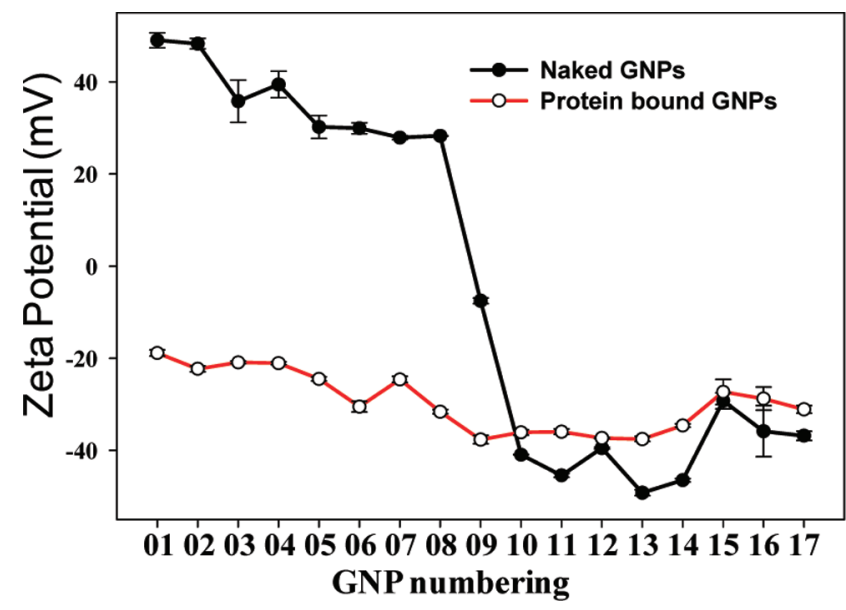

Figure 6. Zeta potential of the GNP array in water and in proteinbound forms. Error bars represent \pm standard deviation.

Effective SCD Determines the Electronic Attraction between NPs and Cells. The electrostatic properties of a particle in solution are determined by the particle itself and its immediate microenvironment. Such properties for NPs are commonly characterized by their zeta potential, which reflects the potential difference between the medium and the fluid layer on the NP. Although some GNPs in the array were overloaded with charged ligands, their effective SCDs on the outmost layer of the NPs might have been lower due to the mutual shielding effect and solvation. The effective SCDs of the naked GNPs were estimated by their zeta potential in water. The zeta potential values of the array in water showed a sharp transition at the neutral GNP09 and the leveling effect for highly positively and negatively charged GNPs (Figure 6), suggesting that the SCD of the outmost layer of NPs defines the electrostatic properties of NPs. We have termed this the effective SCD, which is determined after accounting for the
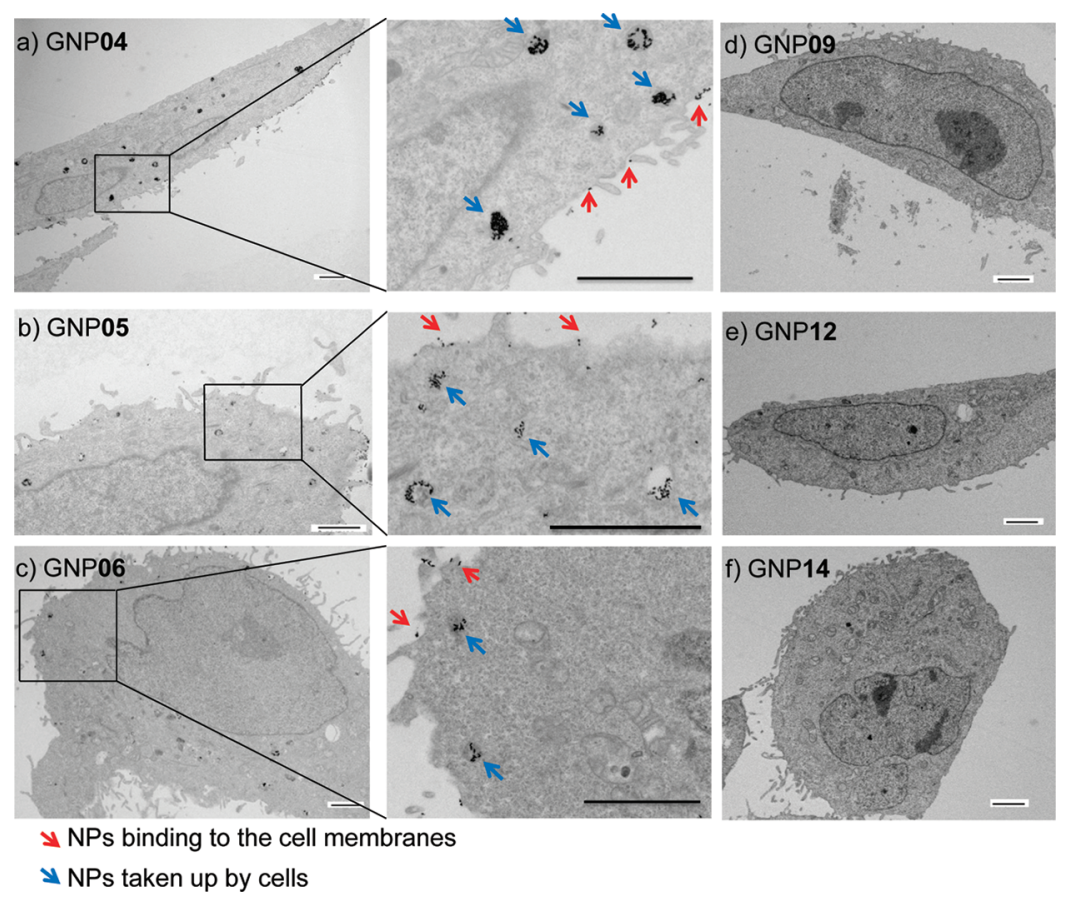

NPs binding to then up by cells

Figure 5. TEM images of Hela cells incubated with $50 \mu \mathrm{g} / \mathrm{mL}$ of GNPs for $12 \mathrm{~h}$. Scale bar is $2 \mu \mathrm{m}$. 
mutual shielding effects of ligands and the surface solvation in solution. The effective SCD was quite different from the SCD determined by the number of ligands on each NP and the number of charged groups on each ligand. The trend of the cell binding and uptake of the array (Figure $4 \mathrm{~b}$ ) was similar to that of effective SCD as measured by the zeta potential in water (Figure 6). However, the transition points were different: GNP09 for effective SCD and GNP05 for cell uptake. GNP06, GNP07, and GNP08, although positively charged, did not initiate cell binding and uptake, suggesting that a threshold of effective SCD is required for this process. When two ideal point charges are attracted to each other, no threshold is expected. However, when nanometer-sized particles and the even larger cell meet, multiple repulsion forces may exist and certain threshold of electrostatic charges on both sides may be needed for their binding.

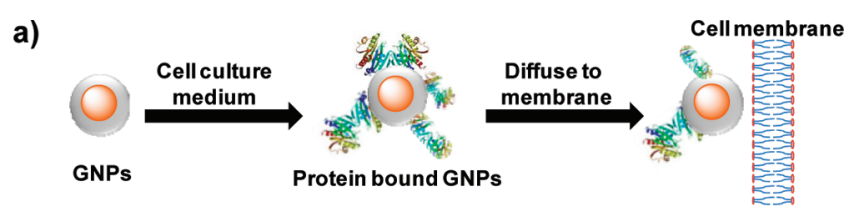

b)

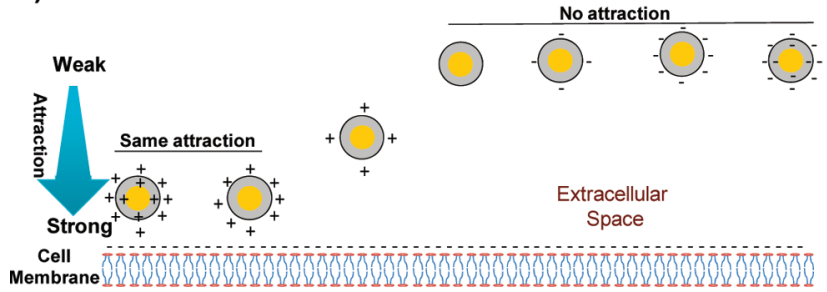

Figure 7. Electrostatic attraction between NPs and cells. (a) Illustration showing how protein-bound GNPs are attracted to cells. (b) Different degrees to which the GNP interacts with the cell membrane.

Binding Proteins on NPs Have No Effect on the Electrostatic Attraction between NPs and Cells. In human blood or in a cell culture medium, NPs are often associated with proteins, which can alter the electrostatic behaviors of NPs. ${ }^{44,45}$ Electrophoretic analysis of the NP-associated proteins $^{46}$ indicated that GNPs bound to a large number of proteins in varying amounts (Figure S3). LC/MS/MS analysis of the GNP-associated proteins showed that each GNP bound to $\sim 60$ proteins, of which $\sim 30$ were common proteins that bound to all NPs (Table S4). The zeta potential values of these protein-bound GNPs were all negative and nearly leveled off for all NPs, varying from -20 to $-30 \mathrm{mV}$. The electrostatic properties of protein-bound GNPs in solution did not correlate with the cell uptake capability of GNPs, suggesting that the protein-binding modifications do not influence NP-cell electrostatic attraction. Protein binding to NPs is a dynamic process. NP-associated proteins maintain an equilibrium between on and off states. Therefore, the effective SCD of the outmost layer of NPs, not the protein-modified NPs, plays a key role in the electrostatic attraction between NP and cells.

\section{CONCLUSION}

In summary, our results demonstrate that although we have synthesized a NP array with a continuous change in SCD, it is not possible to maintain an array with a continuous change in electrostatic properties in solution. The effective SCD on the outmost layer of NPs determines the electrostatic behavior of NPs in solution and their electrostatic attractions to cells with no or identical secondary nonelectrostatic NP-cell interactions. When NPs were dispersed in cell culture medium, only positively charged NPs can be attracted to and taken up by cells if they can cross a set threshold (Figure 7b). Further NP binding with proteins (Figure $7 \mathrm{a}$ ) can almost entirely eliminate electrostatic differences between the positively and negatively charged NPs. Although protein coatings on NPs may help initiate antigen or receptor recognition, they do not play a significant role in determining $\mathrm{NP}-$ cell electrostatic attractions.

\section{ASSOCIATED CONTENT}

\section{Supporting Information}

Preparation and characterization of the ligand 3; SCD calculation; binding protein separation by gel electrophoresis; binding protein identification by LC/MS/MS; cell images of dark-field microscopy; cytotoxicity of the GNP array. This material is available free of charge via the Internet at http:// pubs.acs.org.

\section{AUTHOR INFORMATION}

\section{Corresponding Author}

*Phone: (901) 495-2797. Fax: (901) 495-5715. E-mail: dr. bingyan@gmail.com.

\section{Notes}

The authors declare no competing financial interest.

\section{ACKNOWLEDGMENTS}

We thank Andrew Lemoff, Lei Yang, Patrick Rodrigues, Robert Cassell, Sharon Frase, Jacqueline Williams, and Vishwajeeth Pagala for technical assistance. This work was supported by the National Basic Research Program of China (2010CB933504), the National Natural Science Foundation of China (90913006, 21077068, and 21137002), the National Cancer Institute (P30CA027165), NIH (CA096832 and CA21765 for MFR), and the American Lebanese Syrian Associated Charities (ALSAC).

\section{REFERENCES}

(1) Farokhzad, O. C.; Langer, R. ACS Nano 2009, 3 (1), 16-20.

(2) Giljohann, D. A.; Seferos, D. S.; Daniel, W. L.; Massich, M. D.; Patel, P. C.; Mirkin, C. A. Angew. Chem., Int. Ed. 2010, 49 (19), 32803294.

(3) Wang, A. Z.; Langer, R. S.; Farokhzad, O. C. Annu. Rev. Med., in press.

(4) Karakoti, A.; Hench, L.; Seal, S. JOM 2006, 58 (7), 77-82.

(5) Hussain, S. M.; Braydich-Stolle, L. K.; Schrand, A. M.; Murdock, R. C.; Yu, K. O.; Mattie, D. M.; Schlager, J. J.; Terrones, M. Adv. Mater. 2009, 21 (16), 1549-1559.

(6) Su, G.; Yan, B. J. Comb. Chem. 2010, 12 (2), 215-221.

(7) Nel, A. E.; Madler, L.; Velegol, D.; Xia, T.; Hoek, E. M. V.; Somasundaran, P.; Klaessig, F.; Castranova, V.; Thompson, M. Nature Mater. 2009, 8 (7), 543-557.

(8) Verma, A.; Stellacci, F. Small 2010, 6 (1), 12-21.

(9) Kim, B.; Han, G.; Toley, B. J.; Kim, C.-k.; Rotello, V. M.; Forbes, N. S. Nature Nanotechnol. 2010, 5 (6), 465-472.

(10) Harris, T. J.; Green, J. J.; Fung, P. W.; Langer, R.; Anderson, D. G.; Bhatia, S. N. Biomaterials 2009, 31 (5), 998-1006.

(11) He, C.; Hu, Y.; Yin, L.; Tang, C.; Yin, C. Biomaterials 2010, 31 (13), 3657-3666.

(12) Schleh, C.; Semmler-Behnke, M.; Lipka, J.; Wenk, A.; Hirn, S.; Schäffler, M.; Schmid, G. N.; Simon, U.; Kreyling, W. G. Nanotoxicology 2010, 1-11. 
(13) Xiao, K.; Li, Y.; Luo, J.; Lee, J. S.; Xiao, W.; Gonik, A. M.; Agarwal, R. G.; Lam, K. S. Biomaterials 2011, 32 (13), 3435-3446.

(14) Chung, T.-H.; Wu, S.-H.; Yao, M.; Lu, C.-W.; Lin, Y.-S.; Hung, Y.; Mou, C.-Y.; Chen, Y.-C.; Huang, D.-M. Biomaterials 2007, 28 (19), 2959-2966.

(15) Leroueil, P. R.; Hong, S.; Mecke, A.; Baker, J. R; Orr, B. G.; Banaszak Holl, M. M. Acc. Chem. Res. 2007, 40 (5), 335-342.

(16) Patil, S.; Sandberg, A.; Heckert, E.; Self, W.; Seal, S. Biomaterials 2007, 28 (31), 4600-4607.

(17) Dausend, J.; Musyanovych, A.; Dass, M.; Walther, P.; Schrezenmeier, H.; Landfester, K.; Mailänder, V. Macromol. Biosci. 2008, 8 (12), 1135-1143.

(18) Harush-Frenkel, O.; Rozentur, E.; Benita, S.; Altschuler, Y. Biomacromolecules 2008, 9 (2), 435-443.

(19) Cho, E. C.; Xie, J.; Wurm, P. A.; Xia, Y. Nano Lett. 2009, 9 (3), 1080-1084.

(20) Mu, Q.; Broughton, D. L.; Yan, B. Nano Lett. 2009, 9 (12), $4370-4375$.

(21) Zhang, L. W.; Monteiro-Riviere, N. A. Toxicol. Sci. 2009, 110 (1), 138-155.

(22) Arvizo, R. R.; Miranda, O. R.; Thompson, M. A.; Pabelick, C. M.; Bhattacharya, R.; Robertson, J. D.; Rotello, V. M.; Prakash, Y. S.; Mukherjee, P. Nano Lett. 2010, 10 (7), 2543-2548.

(23) Asati, A.; Santra, S.; Kaittanis, C.; Perez, J. M. ACS Nano 2010, 4 (9), 5321-5331.

(24) Liang, M.; Lin, I. C.; Whittaker, M. R.; Minchin, R. F.; Monteiro, M. J.; Toth, I. ACS Nano 2010, 4 (1), 403-413.

(25) Schaeublin, N. M.; Braydich-Stolle, L. K.; Schrand, A. M.; Miller, J. M.; Hutchison, J.; Schlager, J. J.; Hussain, S. M. Nanoscale 2011, 3 (2), 410-420.

(26) Lewinski, N.; Colvin, V.; Drezek, R. Small 2008, 4 (1), 26-49.

(27) Nan, A.; Bai, X.; Son, S. J.; Lee, S. B.; Ghandehari, H. Nano Lett. 2008, 8 (8), 2150-2154.

(28) Alkilany, A. M.; Nagaria, P. K.; Hexel, C. R.; Shaw, T. J.; Murphy, C. J.; Wyatt, M. D. Small 2009, 5 (6), 701-708.

(29) Bhattacharjee, S.; de Haan, L.; Evers, N.; Jiang, X.; Marcelis, A.; Zuilhof, H.; Rietjens, I.; Alink, G. Part. Fibre Toxicol. 2010, 7 (1), 25.

(30) Gessner, A.; Lieske, A.; Paulke, B. R.; Müller, R. H. Eur. J. Pharm. Biopharm. 2002, 54 (2), 165-170.

(31) Mu, Q.; Liu, W.; Xing, Y.; Zhou, H.; Li, Z.; Zhang, Y.; Ji, L.; Wang, F.; Si, Z.; Zhang, B.; Yan, B. J. Phys. Chem. C 2008, 112 (9), 3300-3307.

(32) Deng, Z. J.; Mortimer, G.; Schiller, T.; Musumeci, A.; Martin, D.; Minchin, R. F. Nanotechnology 2009, 20, 45.

(33) Wille, H.; Shanmugam, M.; Murugesu, M.; Ollesch, J.; Stubbs, G.; Long, J. R.; Safar, J. G.; Prusiner, S. B. Proc. Natl. Acad. Sci. U. S. A. 2009, 106 (10), 3740-3745.

(34) Ghosh, P. S.; Kim, C.-K.; Han, G.; Forbes, N. S.; Rotello, V. M. ACS Nano 2008, 2 (11), 2213-2218.

(35) Mintzer, M. A.; Simanek, E. E. Chem. Rev. 2008, 109 (2), 259302.

(36) Shmueli, R. B.; Anderson, D. G.; Green, J. J. Expert Opin. Drug Delivery 2010, 7 (4), 535-550.

(37) Pittella, F.; Zhang, M.; Lee, Y.; Kim, H. J.; Tockary, T.; Osada, K.; Ishii, T.; Miyata, K.; Nishiyama, N.; Kataoka, K. Biomaterials 2011, 32 (11), 3106-3114.

(38) Sanjoh, M.; Hiki, S.; Lee, Y.; Oba, M.; Miyata, K.; Ishii, T.; Kataoka, K. Macromol. Rapid Commun. 2010, 31 (13), 1181-1186.

(39) Kim, C.; Agasti, S. S.; Zhu, Z.; Isaacs, L.; Rotello, V. M. Nature Chem. 2010, 2 (11), 962-966.

(40) Oshrat, H.-F.; Yoram, A.; Simon, B. Crit. Rev. Ther. Drug Carrier Syst. 2008, 25 (6), 485-544.

(41) Zhou, H.; Li, X.; Lemoff, A.; Zhang, B.; Yan, B. Analyst 2010, 135 (6), 1210-1213.

(42) Daniel, M.-C.; Tsvetkova, I. B.; Quinkert, Z. T.; Murali, A.; De, M.; Rotello, V. M.; Kao, C. C.; Dragnea, B. ACS Nano 2010, 4 (7), 3853-3860.

(43) Ma, Y.; Zhuang, Y.; Xie, X.; Wang, C.; Wang, F.; Zhou, D.; Zeng, J.; Cai, L. Nanoscale 2011, 3 (5), 2307-2314.
(44) Giljohann, D. A.; Seferos, D. S.; Patel, P. C.; Millstone, J. E.; Rosi, N. L.; Mirkin, C. A. Nano Lett. 2007, 7 (12), 3818-3821.

(45) Cho, E. C.; Zhang, Q.; Xia, Y. Nature Nanotechnol. 2011, 6 (6), 385-391.

(46) Li, L.; Zhang, Q.; Liu, A.; Li, X.; Zhou, H.; Liu, Y.; Yan, B. J. Am. Chem. Soc. 2011, 133 (18), 6886-6889. 